\title{
EVALUASI PELAKSANAAN PROGRAM PENGEMBANGAN PERUMAHAN (STUDI PADA KANTOR DINAS PERUMAHAN DAN KAWASAN PERMUKIMAN KOTA PALEMBANG)
}

\author{
Yuliana \\ Staf Dosen Fakultas Ilmu Administrasi Universitas Sjakhyakirti \\ Email: yuliana@pps-unisti.ac.id
}

\begin{abstract}
Housing and settlements are basic human needs. Therefore, the government is trying to meet the community's need for housing. This study aims to see how the housing development program is implemented in Palembang City, monitor this program and also monitor the extent of the housing development program. This research uses descriptive qualitative techniques with interviews. Key information is the Head of the Palembang City Housing and Settlement Area Office, the Head of the Housing and Settlements Section, the Head of the Palembang City Development Planning Agency, and Housing Developers in Palembang City, as well as people living in housing in Palembang City. Then the data obtained from the study were analyzed using qualitative descriptive analysis methods. The results showed that the implementation of the housing development program in Palembang City has not been carried out properly in accordance with what has been planned by the Palembang City Government.
\end{abstract}

Keywords: Evaluation, Housing Development Program

\begin{abstract}
ABSTRAK
Perumahan dan permukiman merupakan kebutuhan dasar manusia. Oleh karena itu, pemerintah berupaya memenuhi kebutuhan masyarakat akan perumahan. Penelitian ini bertujuan untuk mengetahui bagaimana pelaksanaan program pengembangan perumahan di Kota Palembang, untuk mengetahui kendala - kendala yang dihadapi dalam pelaksanaan program ini dan juga untuk mengetahui sudah sejauh mana keberhasilan program pengembangan perumahan ini. Penelitian ini menggunakan teknik kualitatif deskriptif dengan metode wawancara. Informan kunci yaitu Kepala Dinas Perumahan dan Kawasan Permukiman Kota Palembang, Kepala Bagian Perumahan dan Permukiman, Kepala Badan Perencanaan Pembangunan Kota Palembang, dan Developer (Pengembang) Perumahan di Kota Palembang, serta masyarakat yang tinggal di perumahan yang ada di Kota Palembang. Kemudian data yang diperoleh dari penelitian tersebut dianalisa dengan metode analisa deskriptif kualitatif. Hasil penelitian menunjukkan bahwa pelaksanaan program pengembangan perumahan di Kota Palembang belum terlaksana dengan baik sesuai dengan apa yang telah direncanakan oleh Pemerintah Kota Palembang.
\end{abstract}

Kata Kunci: Evaluasi, Program Pengembangan Perumahan

\author{
PENDAHULUAN \\ Latar Belakang \\ Perumahan dan permukiman \\ merupakan kebutuhan dasar manusia. \\ Kebutuhan akan perumahan dan \\ permukiman sebagai hak asasi dan hak \\ dasar setiap manusia diakui secara \\ universal, menjadi landasan hukum
}

internasional dan dituangkan dalam DUHAM (Deklarasi Umum Hak-hak Asasi Manusia) Pasal 25 ayat (1). Di Indonesia hal ini terdapat dalam pasal 28 ayat 1 Undang-Undang Dasar RI tahun 1945, bahwa setiap orang memiliki hak hidup sejahtera lahir dan bathin, bertempat tinggal dan mendapatkan 
lingkungan hidup yang baik dan sehat. Dalam situasi apapun orang pasti berupaya memiliki rumah sebagai tempat tinggal bagi dirinya dan keluarganya, mengembangkan hubungan sosial dan membangun lingkungan permukimannya. Rumah sangat bermakna bagi eksistensi seorang manusia, baik sebagai pribadi, keluarga dan masyarakat. Tanpa campur tangan pihak lain dari luar lingkungan, mereka pun akan mengusahakan penyelenggaraan rumah dan permukimannya sendiri secara mandiri dan berdaulat. Terjadi dikotomi antara aksesibilitas terhadap sumber daya perumahan dan permukiman yang semakin terbatas dan mahal, dengan kebutuhan akan lokasi tempat tinggal yang aksesibel pada tempat kerja dan usaha, fasilitas umum dan pusat layanan publik. Diperkuat realitas tekanan sosial, ekonomi dan kependudukan, maka situasi inilah yang mendorong terjadinya konsentrasi perumahan dan permukiman yang padat, miskin dan kumuh. Penguasaan dan penggunaan lahan oleh warga masih banyak yang lemah dari sisi hukum dan administrasi; seperti: bantaran sungai, pinggiran rel, tanah makam, tanah in-absentia atau menganggur maupun lahan dalam status penguasaan atau pemilikan pihak lain.

Dalam hal pembangunan di segala bidang khususnya pembangunan perumahan dan permukiman, masyarakat berperan sebagai pelaku utama, sementara pemerintah mempunyai kewajiban sebagai pihak yang berkewajiban yang bertugas mengarahkan, membimbing, dan menciptakan suasana kondusif. Demi tercapainya tujuan pembangunan nasional maupun daerah, kegiatan masyarakat dan pemerintah harus saling mendukung dan melengkapi sehingga terjadi satu kesatuan langkah.
Dalam paradigma lama dan kepentingan konvensional pembangunan perkotaan, lingkungan demikian sering berhadapan dengan masalah penggusuran. Hal tersebut menjadi salah satu bentuk konflik sosial pembangunan dan pengingkaran hak dasar atas perumahan dan permukiman di daerah perkotaan.

Apabila dilihat secara makro, dalam pembangunan khususnya pembangunan perumahan dan permukiman, seharusnya dilakukan sinkronisasi antara dua sistem, yaitu perkotaan dan pedesaan. Hal ini harus diupayakan guna menghindari terjadinya over load (kelebihan beban) pada lingkungan perumahan dalam wilayah perkotaan yang dapat menimbulkan dampak yang tidak menguntungkan bagi wilayah perkotaan maupun wilayah di belakangnya (hinterland), yang biasanya adalah wilayah pedesaan.

Oleh karena itu perencanaan pembangunan sebuah perumahan memegang peranan yang sangat penting dalam mengendalikan laju pembangunan agar berdampak positif dan berkesinambungan. Perencanaan itu harus dimulai dari perencanaan rumahrumah hingga perencanaan lingkungan permukiman, ruang perkotaan, dan skema wilayahnya.

Salah satu landasan yang digunakan oleh pemerintah untuk meningkatkan peran kelembagaan dalam pembangunan perumahan dan permukiman adalah Undang-Undang Nomor 4 tahun 1992 tentang Perumahan dan Permukiman. Pembangunan perumahan dan permukiman sebagai bagian dari program pembangunan nasional sebetulnya sudah dicanangkan semenjak pemerintahan orde baru dalam Pembangunan Jangka Panjang tahap I, dengan target terpenuhinya kebutuhan akan sarana dan 
prasarana dasar serta meningkatnya mutu lingkungan perumahan dan permukiman baik di perkotaan maupun di pedesaan. Adapun realisasi dari pembangunan perumahan dan permukiman dalam PJP I itu dilaksanakan melalui berbagai program antara lain program perumahan rakyat, program penyediaan air bersih, dan program penyehatan lingkungan permukiman dan juga dilaksanakan program penunjang yang berupa pengembangan sistem pembiayaan, pengembangan teknologi perumahan dan permukiman yang memberi dukungan operasional dalam rangka pembangunan fisik perumahan dan permukiman, serta pemantapan dan peningkatan kelembagaan maupun penyiapan peraturan perundang-undangannya.

Program pengembangan perumahan yang telah ditetapkan dalam Rencana Pembangunan Jangka Menengah Nasional (RPJM NAS.) dijadikan acuan daerah baik tingkat satu maupun tingkat dua dalam menyusun Rencana Pembangunan Jangka Menengah Daerah. Hal inilah yang mendasari pemerintah Kota Palembang menetapkan program ini menjadi salah satu program pembangunannya, yang pada dasarnya dilatarbelakangi pada keterbatasan masyarakat berpenghasilan rendah untuk memiliki rumah tinggal sendiri. Oleh karena itu, dengan adanya program ini diharapkan masyarakat akan memiliki rumah tinggal sendiri. Pada Kota ini, program Pengembangan Perumahan termasuk kategori Multy Years Program, artinya program ini selalu termasuk ke dalam program kerja tahunan Dinas Perumahan dan Kawasan Permukiman Kota Palembang.

Ada dua tujuan yang ditetapkan oleh pemerintah Kota Palembang berkaitan dengan program pengembangan perumahan tersebut, yaitu: pertama, mendorong pemenuhan kebutuhan rumah yang layak, sehat, aman, dan terjangkau dengan menitikberatkan kepada masyarakat miskin dan berpendapatan rendah; kedua, meningkatkan kualitas perumahan melalui penguatan lembaga komunitas dalam rangka pemberdayaan sosial kemasyarakatan agar tercipta masyarakat yang produktif secara ekonomi dan berkemampuan mewujudkan terciptanya pemukiman yang sehat, harmonis, dan berkelanjutan.

Di Kota Palembang terdapat lima kawasan perumahan yaitu, di kawasan Ilir Barat, Kenten hingga ke Sukabangun, Alang-Alang Lebar Soekarno Hatta, Plaju Jakabaring, dan Gandus. Dari kelima kawasan perumahan tersebut, belum ada yang selesai tahap pembangunannya. Perumahanperumahan yang ada di kawasan tersebut ada yang sudah selesai tahap pembangunan dan ada juga yang masih dalam tahap pembangunan. Permasalahan yang dihadapi dalam pelaksanaan pembangunan perumahan tersebut terletak pada pendanaan sehingga pembangunan perumahan tersebut terkadang dihentikan untuk sementara waktu. Hal ini mengakibatkan pemerintah terkesan tidak serius dalam pelaksanaan program pengembangan perumahan ini.

Berdasarkan latar belakang di atas, penulis merasa tertarik untuk melakukan penelitian dengan judul : "EVALUASI PELAKSANAAN PROGRAM PENGEMBANGAN PERUMAHAN" ( Studi Pada Kantor Dinas Perumahan dan Kawasan Permukiman Kota Palembang). Berdasarkan latar belakang yang telah diuraikan diatas, maka penulis membuat 
perumusan masalah sebagai berikut : "Bagaimanakah evaluasi pelaksanaan program pengembangan perumahan di Kota Palembang sejak dituangkan dalam Rencana Pembangunan Jangka Menengah Daerah tahun 2014-2019”.

\section{KERANGKA TEORI}

Evaluasi

Menurut O.Jones (1994:357), evaluasi adalah suatu aktifitas yang dirancang untuk menimbang manfaat program dan semua proses pemerintahan. Ia bervariasi dalam spesifikasi kriteria, teknik pengukuran, metode analisis, dan bentuk rekomendasi. Spesifikasi mengacu pada identifikasi tujuan-tujuan serta criteria yang harus dievaluasi. Pengukuran mengacu pada pengumpulan informasi yang relevan dengan tujuan dan analisis adalah penerapan dan penggunaan informasi yang dikumpulkan guna membuat kesimpulan, sedangkan rekomendasi adalah suatu penentuan mengenai apa yang akan dilakukan selanjutnya.

Evaluasi dilakukan dengan maksud untuk dapat mengetahui dengan pasti apakah pencapain hasil kemajuan, dan kendala yang dijumpai dalam pelaksanaan rencana pembangunan dapat dinilai dan dipelajari untuk perbaikan di masa yang akan datang. Fokus utama evaluasi diarahkan kepada keluaran (outputs), hasil (outcomes), dan dampak (impacts) dari pelaksanaan rencana pembangunan. Oleh karena itu, dalam perencanaan yang transparan dan akuntabel, harus disertai dengan penyusunan indicator kinerja pelaksanaan rencana yang sekurangkurangnya meliputi;(i) indikator masukan, (ii) indikator keluaran, dan (iii) indikator hasil (dalam Penjelasan PP No.39 tahun 2006, pasal 12).

Jadi, evaluasi merupakan suatu pemeriksaan terhadap pelaksanaan suatu program yang telah dilakukan yang akan digunakan untuk meramalkan, memperhitungkan, dan mengendalikan pelaksanaan program kedepannya agar jauh lebih baik. Dengan demikian evaluasi lebih bersifat melihat ke depan daripada melihat kesalahan-kesalahan di masa lalu, dan diarahkan pada upaya peningkatan kesempatan demi keberhasilan program.

\section{Perumahan}

Dalam Undang-Undang Nomor 4 tahun 1992 tentang perumahan dan permukiman, perumahan diartikan sebagai kelompok rumah yang berfungsi sebagai lingkungan tempat tinggal atau lingkungan hunian yang dilengkapi dengan sarana dan prasarana. Secara fisik perumahan merupakan sebuah lingkungan yang terdiri dari kumpulan unit-unit rumah tinggal dimana dimungkinkan terjadinya interaksi sosial diantara penghuninya, serta dilengkapi prasarana sosial, ekonomi, budaya, dan pelayanan yang merupakan subsistem dari kota secara keseluruhan. Lingkungan ini biasanya mempunyai aturan-aturan, kebiasaan-kebiasaan serta sistem nilai yang berlaku bagi warganya.

\section{Aspek-aspek Perencanaan Perumahan}

1. Lingkungan

2. Daya Beli

3. Kelembagaan

\section{Program Pembangunan Perumahan dan} Permukiman

Program yang dijalankan dalam pembangunan perumahan dan permukiman oleh pemerintah, terdiri dari program pokok dan program pendukung, yaitu sebagai berikut:

\section{Program Pokok}

a. Program Penyediaan

Perumahan dan Permukiman 
b. Program perbaikan perumahan dan permukiman

c. Program penyehatan lingkungan permukiman

d. Program penyediaan dan pengelolaan sarana air bersih

e. Program Penataan Kota

f. Program Penataan Bangunan

2. Program Pendukung Program pendukung dalam pembangunan perumahan dan permukiman mutlak diperlukan karena program inilah yang akan mendukung pelaksanaan pembangunan dan permukiman. Program pendukung dalam pembangunan perumahan dan permukiman antara lain berupa Program Penelitian dan Pengenbangan Perumahandan Permukiman serta Program Penyelamatan Hutan, Tanah, dan Air.

\section{Kebijakan dan Strategi Nasional Perumahan dan Permukiman}

1. Melembagakan sistem penyelenggaraan perumahan dan permukiman dengan melibatkan masyarakat (partisipatif) sebagai pelaku utama, melalui strategi:
a. Penyusunan, pengembangan dan
sosialisasi berbagai produk peraturan perundangundangan dalam penyelenggaraan perumahan dan permukiman.
b. Pemantapan kelembagaan perumahan dan permukiman yang handal dan responsif.
c. Pengawasan konstruksi dan keselamatan bangunan gedung dan lingkungan.

2. Mewujudkan pemenuhan kebutuhan perumahan bagi seluruh lapisan masyarakat, melalui strategi:

a. Pengembangan sistem pembiayaan dan pemberdayaan pasar perumahan (primer dan sekunder), meliputi (a) Peningkatan kualitas

$\begin{array}{lcr}\text { pasar primer } & \text { melalui } \\ \text { penyederhanaan } & \text { perijinan, } \\ \text { sertifikasi hak atas } & \text { tanah, } \\ \text { standarisasi penilaian } & \text { kredit, } \\ \text { dokumentasi } & \text { kredit, } & \text { dan }\end{array}$
pengkajian ulang peraturan terkait; (b) Pelembagaan pasar sekunder melalui SMF (Secondary Mortgage Facilities), biro kedit, asuransi kredit, lembaga pelayanan dokumentasi kredit; dan lembaga sita jaminan.

b. Pengembangan pembangunan perumahan yang bertumpu keswadayaan masyarakat, meliputi (a) Pelembagaan pembangunan perumahan bertumpu pada kelompok masyarakat (P2BPK); (b) Pengembangan dan pendayagunaan potensi keswadayaan masyarakat; (c) Pemberdayaan para pelaku kunci perumahan swadaya; serta (d) Pengembangan akses pembiayaan perumahan swadaya.

c. Pengembangan berbagai jenis dan mekanisme subsidi perumahan, dapat berbentuk subsidi pembiayaan; subsidi prasarana dan sarana dasar lingkungan perumahan dan permukiman; ataupun kombinasi kedua subsidi tersebut.

d. Pemberdayaan usaha ekonomi masyarakat miskin, meliputi (a) Pemberdayaan masyarakat untuk mengembangkan kemampuan usaha dan hidup produktif; (b) Penyediaan kemudahan akses kepada sumber daya serta prasarana dan sarana usaha bagi keluarga miskin, serta (c) Pelatihan teknologi tepat guna, pengembangan kewirausahaan, serta keterampilan lainnya.

e. Pemenuhan kebutuhan perumahan 
dan permukiman akibat dampak bencana alam dan kerusuhan sosial, meliputi (a) Penanganan tanggap darurat; (b) Rekonstruksi dan rehabilitasi bangunan, prasarana dan sarana dasar perumahan dan permukiman; serta (c) Pemukiman kembali pengungsi. Penanganan tanggap darurat merupakan upaya yang harus dilakukan dalam rangka penanganan pengungsi, penyelamatan korban dampak bencana alam atau kerusuhan sosial, sebelum proses lebih lanjut seperti pemulangan, pemberdayaan, dan pengalihan (relokasi).

f. Pengelolaan bangunan gedung dan rumah negara, melalui pembinaan teknis penyelenggaraan dan pengelolaan aset bangunan gedung dan rumah negara.

3. Mewujudkan permukiman yang sehat, aman, harmonis dan berkelanjutan guna mendukung pengembangan jatidiri, kemandirian, dan produktivitas masyarakat, melalui strategi:

a. Peningkatan kualitas lingkungan permukiman, dengan prioritas kawasan permukiman kumuh di perkotaan dan pesisir, meliputi (a) Penataan dan rehabilitasi kawasan permukiman kumuh; (b) Perbaikan prasarana dan sarana dasar permukiman; serta (c) Pengembangan rumah sewa, termasuk rumah susun sederhana sewa (rusunawa).

b. Pengembangan penyediaan prasarana dan sarana dasar permukiman, meliputi (a) Pengembangan kawasan siap bangun (Kasiba) dan lingkungan siap bangun (Lisiba); dan (b) Pengembangan lingkungan siap bangun yang berdiri sendiri, yang berdasarkan RTRW Kabupaten atau Kota, dan Rencana Pembangunan dan Pengembangan Perumahan dan Permukiman di Daerah (RP4D) yang telah ditetapkan melalui peraturan daerah. Kasiba dan Lisiba tersebut dimaksudkan untuk mengembangkan kawasan permukiman skala besar secara terencana dan terpadu dalam manajemen kawasan yang efektif. Dalam pengembangan Kasiba dan Lisiba serta kaitannya dengan pengelolaan tata guna tanah, juga perlu dipertimbangkan pengembangan Bank Tanah untuk lebih mengendalikan harga tanah.

c. Penerapan tata lingkungan permukiman, meliputi (a) Pelembagaan RP4D, yang merupakan pedoman perencanaan, pemrograman, pembangunan dan pengendalian pembangunan jangka menengah dan panjang secara sinergi melibatkan kemitraan pemerintah, dunia usaha dan masyarakat; (b) Pelestarian bangunan bersejarah dan lingkungan permukiman tradisional; (c) Revitalisasi lingkungan permukiman strategis; serta (d) Pengembangan penataan dan pemantapan standar pelayanan minimal lingkungan permukiman untuk mencegah perubahan fungsi lahan, menghindari upaya penggusuran, 
mengembangkan pola hunian berimbang, menganalisis dampak lingkungan melalui Analisa Mengenai Dampak Lingkungan AMDAL), Rencana Pengelolaan Lingkungan (RKL), Rencana Pemantauan Lingkungan (RPL), serta Upaya Pengelolaan Lingkungan (UKL) dan Upaya Pemantauan Lingkungan (UPL) secara konsisten.

\section{Evaluasi Pelaksanaan Program Pengembangan Perumahan}

Salah satu upaya untuk merespon sistem perencanaan pembangunan yang komprehensif dan mengarah kepada perwujudan transparansi, demokratisasi, desentralisasi, dan partisipasi masyarakat, pemerintah telah mengundangkan Undang-Undang Nomor 25 Tahun 2004 tentang Sistem Perencanaan Pembangunan Nasional (SPPN), yang didalamnya diatur sistem perencanaan pembangunan yang baru yang terdiri dari empat tahapan, yaitu: (1) penyusunan rencana; (2) penetapan rencana; pengendalian pelaksanaan rencana; (4) evaluasi pelaksanaan rencana. Perencanaan, pelaksanaan, pengendalian, dan evaluasi pelaksanaan rencana merupakan bagian-bagian dari fungsi manajemen yang saling terkait dan tidak dapat dipisahkan satu sama lain.

Program-program pembangunan khususnya program pengembangan perumahan yang telah ditetapkan oleh pemerintah pada saat ini memerlukan suatu pengevaluasian untuk mengetahui sudah sampai sejauh mana pelaksanaannya karena hal ini berkaitan dengan aspek transparansi dan akuntabilitas kinerja pemerintah terhadap pihak-pihak yang berkepentingan.

Evaluasi pelaksanaan program pengembangan perumahan ini dilakukan untuk menilai pencapaian pelaksanaan program tersebut, efektifitas, efisiensi, manfaat, dampak, dan keberlanjutan dari program tersebut. Pengevaluasian ini juga menggunakan indikatorindikator yang digunakan dalam penyusunan program pengembangan perumahan ini yang dituangkan dalam Rencana Pembangunan Jangka Menengah Kota Palembang. Dan apakah program ini telah sesuai dengan apa yang menjadi tujuan yang telah ditetapkan oleh pemerintah daerah yaitu terpenuhinya kebutuhan akan rumah yang sehat, aman, serasi dengan lingkungan, terjangkau masyarakat terutama yang berpenghasilan menengah dan rendah dan juga meningkatkan kualitas perumahan melalui penguatan komunitas lembaga yang ada dalam rangka peningkatan kualitas sosial kemaasyarakatan.

Evaluasi pelaksanaan program pengembangan perumahan diukur dengan indikator :

1. Pelaksanaan Program Pengembangan Perumahan

a. Kemampuan organisasi melaksanakan program, meliputi :

- Kemampuan sumber daya manusia

- Kemampuan mengatur dan menggunakan sumber dana

- Kemampuan mengatur dan menggunakan sumber daya manusia

b. Memasyarakatkan program, meliputi

- Adanya koordinasi antar instansi yang terkait

- Dukungan dari masyarakat

2. Program Pengembangan Perumahan

Tersedianya komponen penyelenggara program, yaitu :

a. Pelaksana program

b. Penilaian Masyarakat

c. Sarana dan prasarana yang digunakan

d. Peraturan dan ketentuan yang mendukung program pengembangan perumahan

3. Keberhasilan pelaksanaan,dengan indikator :

Target dan realisasi pelaksanaan program pengembangan perumahan

\section{METODELOGI PENELITIAN}


Metode penelitian yang digunakan dalam penelitian ini adalah penelitian deskriptif dengan menggunakan analisa kualitatif. populasi dalam penelitian ini adalah pegawai di Kantor Dinas Perumahan dan Kawasan Permukiman Kota Palembang yang berjumlah 65 orang. Teknik penentuan sampel yang digunakan yaitu Proposive Sampling. Adapun yang menjadi informan kunci disini adalah Kepala Dinas Perumahan dan Kawasan Permukiman Kabupaten Tapanuli Utara, Kabid Perumahan dan Permukiman. Dan untuk menambah perbendaharaan data, penulis mengambil sampel dari masyarakat dengan menggunakan teknik sampling insedental, yaitu teknik penentuan sampel berdasarkan kebetulan, yakni siapa saja yang secara kebetulan bertemu dengan peneliti yang dapat digunakan sebagai sampel.

Untuk memperoleh data atau informasi, keterangan-keterangan data yang diperlukan, penulis menggunakan metode sebagai berikut:

1. Pengumpulan Data Primer

a. Wawancara

b. Observasi

\section{Pengumpulan Data Sekunder}

Yaitu cara pengumpulan data melalui studi kepustakaan, dokumentasi, dan bahan lain yang relevan dengan objek penelitian.

Teknik analisa data yang digunakan dalam penelitian ini adalah analisa data kualitatif, yaitu analisa data terhadap data yang diperoleh berdasarkan kemampuan nalar peneliti dalam menghubungkan fakta, data, dan informasi. Jadi teknik analisa data dilakukan dengan penyajian data yang terdapat melalui keterangan yang diperoleh dari responden, selanjutnya diinterpretasikan sesuai dengan tujuan penelitian yang telah dirumuskan.

\section{HASIL PENELITIAN DAN PEMBAHASAN Pelaksanaan Program Pengembangan Perumahan}

Program pengembangan perumahan yang ditetapkan oleh Pemerintah Daerah Kota Palembang dalam Rencana Pembangunan Jangka Menengah baik untuk tingkat nasional maupun daerah ditujukan pada pemenuhan rumah bagi masyarakat yang memiliki tingkat ekonomi lemah ataupun kurang mampu untuk memiliki rumah sendiri. Untuk di Kota Palembang, perumahan yang dibangun oleh pemerintah telah ditujukan untuk masyarakat yang memiliki tingkat ekonomi lemah atau kurang mampu. Hal ini disebabkan karena kemampuan masyarakat ekonomi lemah untuk memiliki rumah sendiri sangat terbatas.

Ada dua tujuan yang ditetapkan oleh pemerintah Kota Palembang berkaitan dengan program pengembangan perumahan tersebut yang disusun di dalam Rencana Pembangunan Jangka Menengah Daerah Kota Palembang periode 2014-2019, yaitu: pertama, mendorong pemenuhan kebutuhan rumah yang layak, sehat, aman, dan terjangkau dengan menitikberatkan kepada masyarakat miskin dan berpendapatan rendah; kedua, meningkatkan kualitas perumahan melalui penguatan lembaga komunitas dalam rangka pemberdayaan sosial kemasyarakatan agar terciptanya masyarakat yang produktif secara ekonomi dan berkemampuan mewujudkan terciptanya pemukiman penduduk yang sehat, harmonis, dan berkelanjutan.

Sedangkan sasaran utama dari pelaksanaan program ini adalah pemenuhan kebutuhan hunian bagi masyarakat melalui terciptanya pasar primer yang sehat, efisien, akuntabel, tidak diskriminatif dan terjangkau oleh seluruh lapisan masyarakat yang didukung oleh sistem pembiayaan perumahan jangka panjang yang efisien dan akuntabel; dan terbentuknya pola subsidi yang tepat sasaran, tidak mendistorsi pasar, akuntabel dan mempunyai kepastian dalam hal ketersediaan setiap tahun.

Dilihat dari tujuan yang telah ditetapkan oleh pemerintah Kota Palembang, program pengembangan perumahan ini mempunyai tujuan dan sasaran yang jelas dimana pelaksanaan program pengembangan perumahan ini pada dasarnya ditujukan kepada masyarakat miskin dan berpendapatan rendah yang memiliki keterbatasan untuk mempunyai rumah tinggal sendiri, dan sasaran dari pelaksanaan program ini yaitu pemenuhan kebutuhan akan rumah oleh masyarakat. Pelaksanaan program ini juga memiliki peraturan yang mendukung pelaksanaannya seperti Undang-undang Nomor 4 tahun 1992 tentang Perumahan dan 
Permukiman, S.K. Menteri Kimpraswil Nomor 217/2002 tentang Kebijaksanaan dan Strategi Nasional Perumahan dan Permukiman (KSNPP), dan Rencana Pembangunan Jangka Menengah Kota Palembang. Ini menunjukkan bahwa dari segi perencanaan, program ini telah memenuhi karakteristik perencanaan yang baik.

Dalam pelaksanaan program ini, juga telah tersedia sumber-sumber yang akan dipergunakan dalam pelaksanaan program ini seperti sumber daya manusia yaitu pegawai Dinas Perumahan dan Kawasan Permukiman, Kota Palembang, sumber dana yang berasal dari APBD Kota Palembang dan dari pemerintah pusat, dan juga fasilitas-fasilitas yang ada di kantor Dinas Perumahan dan Kawasan Permukiman yang sangat membantu dalam pelaksanaan program pengembangan perumahan ini.

Program pengembangan perumahan ini mempunyai pasar yang lumayan banyak yaitu masyarakat yang mempunyai keterbatasan memiliki rumah tinggal sendiri dan juga pegawai negeri sipil yang juga memiliki keterbatasan memiliki rumah. Namun, daya beli masyarakat masih rendah, ada juga masyarakat yang membeli perumahan tersebut, namun perumahan tersebut kebanyakan tidak dihuni atau ditinggali. Hal ini disebabkan karena jarak yang cukup jauh, bangunan yang tidak sesuai dengan standar, prasarana dan sarana yang masih kurang memadai sehingga masyarakat kurang termotivasi untuk tinggal di perumahan tersebut. Pelaksanaan program pengembangan perumahan di Kota Palembang dilaksanakan oleh pemerintah daerah setempat dengan bantuan dari pihak swasta.

Keadaan perumahan di Kota Palembang masih kurang bagus karena disebabkan kurangnya pengawasan yang dilakukan oleh Dinas Perumahan dan Kawasan Permukiman Kota Palembang maupun pemerintah daerah, baik pengawasan terhadap pembangunan rumah yang mengakibatkan rumah yang dibangun tidak sesuai dengan standar rumah yang layak huni sehingga banyak rumah yang sudah dibangun cepat rusak dan juga tidak laku karena tidak sesuai dengan apa yang dibutuhkan oleh masyarakat selaku konsumen, dan juga kurangnya pengawasan terhadap lahan yang akan dijadikan sebagai lokasi perumahan sehingga lahan tersebut sebagian dijadikan sebagai lahan pertanian oleh masyarakat. Pada hal tanah tersebut sudah menjadi milik pemerintah.

Dampak dari kurangnya pengawasan tersebut mengakibatkan pembangunan perumahan lebih terfokus pada perbaikan/rehabilitasi rumah-rumah yang rusak sehingga pembangunan sering terhenti. Ini mengakibatkan anggaran yang seharusnya ditujukan untuk pembangunan rumah baru dialokasikan ke perbaikan rumah. Apabila Dinas Perumahan dan Kawasan Permukiman melakukan pengawasan terhadap pelaksanaan program pengembangan perumahan ini maka proses pelaksanaannya dapat dilakukan sesuai dengan ketentuan-ketentuan yang telah direncanakan, dapat menghemat penggunaan biaya pembangunan rumah, dan tujuan dari pelaksanaan program ini dapat tercapai sesuai dengan apa yang telah ditentukan.

Pengawasan yang dilakukan oleh Dinas Perumahan dan Kawasan Permukiman seharusnya bersifat Cocurent. Pengawasan ini dilakukan secara bersamaan dengan pelaksanaan program pengembangan perumahan ini. Tipe pengawasan ini merupakan proses dimana aspek tertentu dari suatu prosedur harus disetujui terlebih dahulu, atau syarat tertentu harus dipenuhi terlebih dahulu sebelum kegiatan tersebut dilakukan untuk mencapai suatu ketepatan dari pelaksanaan program.

Dilihat dari segi target dari pelaksanaan program ini dimana perumahan yang dibangun telah menyentuh semua lapisan masyarakat, akan tetapi kejadian dilapangan yang menempati perumahan tersebut didominasi oleh masyarakat tergolong kalangan menengah ke atas. Seperti yang ada di daerah Gandus,dDari 57 keluarga yang tinggal di perumahan tersebut, sekitar 38 keluarga merupakan masyarakat dari berbagai profesi seperti PNS, purnawirawan TNI/POLRI, pengusaha, dan pedagang. Ada juga di beberapa wilayah perumahan, sebagian rumah disewakan oleh masyarakat setempat. Hal ini menandakan bahwa pengawasan terhadap masyarakat yang menempati perumahan tersebut masih sangat 
kurang. Ini berdampak pada tujuan dari pelaksanaan pembangunan perumahan yang masih di luar dari yang telah ditentukan sebelumnya. Hal ini menunjukkan kurangnya sosialisasi pelaksanaan program ini kepada masyarakat sehingga tidak ada kejelasan apakah perumahan yang dibangun tersebut ditujukan kepada masyarakat biasa.

$$
\text { Apabila dilihat dari segi }
$$

pengorganisasian, yang menjadi pelaksana program pengembangan perumahan ini antara lain Dinas Perumahan dan Kawasan Permukiman, yang mengurus pelaksanaan pembangunan dan pengembangan perumahan dan fasilitasnya; Dinas Pekerjaan Umum, yang mengurus infrastruktur jalan ke kawasan perumahan; BAPPERTARUM, yang menentukan Developer yang menjadi pelaksana pembangunan perumahan; PLN, yang mengurus pasokan listrik ke tiap-tiap rumah dan lampu jalan; Bank Pelaksana, yang menyediakan dana untuk pembangunan perumahan sesuai dengan anggaran yang dibutuhkan untuk pembangunan perumahan; PDAM, yang mengurus ketersediaan sarana air bersih di lokasi perumahan termasuk sambungan ke tiap-tiap rumah; pemerintah daerah, yang mengawasi pelaksanaan pembangunan; dan Developer (Pengembang), yang menjadi pelaksana pembangunan. Pembagian tugas dari masingmasing Dinas/Instansi tersebut sangat jelas. Dengan adanya pembagian tugas yang jelas tersebut maka diharapkan pelaksanaan program pengembangan perumahan ini berjalan sesuai dengan apa yang telah direncanakan.

Keikutsertaan Dinas/Instansi yang lain tersebut dalam pelaksanaan program pengembangan perumahan dikarenakan jumlah sumber daya manusia yang dibutuhkan dalam program ini cukup banyak dan program pendukung pelaksanaan program ini tidak dapat ditangani sendiri oleh Dinas Perumahan dan Kawasan Permukiman Kota Palembang. Ini menunjukkan adanya koordinasi antar Dinas/Instansi yang serasi (adanya perbandingan yang cocok antara beban tugas dengan pelaksanaan tugas), selaras (adanya sinkronisasi antara staf dengan pimpinan pada hal-hal yang dikehendaki), dan seimbang (adanya pembebanan yang proporsional serta sinkronisasi pelaksanaan tugas di masing- masing bagian dalam unit organisasi).

Sumber daya manusia yang dimiliki

oleh Dinas Perumahan dan Kawasan Permukiman Kota Palembang merupakan salah satu aspek internal yang akan mendukung pelaksanaan program pengembangan perumahan. Disamping strategi yang digunakan dan prioritas pembangunan yang dilakukan oleh Dinas Perumahan dan Kawasan Permukiman. Aspek sumber daya manusia ini dilihat dari segi jumlah sumber daya manusia yang memadai, yang dapat dilihat dari segi kuantitas pegawai yang dimiliki oleh Dinas Perumahan dan Kawasan Permukiman, adanya tugas pokok dan fungsi Dinas Perumahan dan Kawasan Permukiman Kota Palembang dalam menyelenggarakan tata pemerintahan yang baik.Pelaksanaan program pengembangan perumahan ini juga memiliki peluang dalam usaha pemenuhan permintaan akan rumah. Peluang tersebut antara lain:

1. Letak Kota Palembang di jalur lintas sumatera sangat memerlukan perencanaan tata ruang yang baik dan ramah lingkungan. Pembangunan kawasan perumahan ditujukan untuk pemenuhan rumah terutama masyarakat memiliki ekonomi lemah menuntut adanya perencanaan tata ruang untuk meningkatkan kebersihan dan kerapian lingkungan.

2. Dari aspek ekonomi, pembangunan perumahan di Kota Palembang memiliki peluang yang besar dalam kestabilan ekonomi. Dengan adanya penataan kawasan perumahan yang baik, maka setiap kegiatan ynag dilakukan oleh pemerintah, swasta, maupun masyarakat dapat dilakukan dengan baik. Disamping itu, dengan penataan lingkungan yang baik akan mengundang investor untuk menanamkam modalnya di Kota Palembang.

\section{Keberhasilan Pelaksanaan Program Pengembangan Perumahan}

Suatu program dapat dikatakan berhasil apabila target dan realisasi dari program tersebut 
sudah tercapai dengan baik, sesuai dengan apa yang telah direncanakan sebelumnya.Melihat kenyataan di lapangan, program ini masih belum dapat dikatakan berhasil karena program ini masih berjalan dan juga sarana dan prasarana pendukung seperti sarana pendidikan, peribadatan, sarana olah raga pada perumahan ini masih sangat kurang.

Pembangunan perumahan di Kota Palembang yang masih berjalan sampai sekarang memang belum optimal karena disebabkan oleh beberapa faktor seperti kurang meratanya sumber daya manusia pada Dinas Perumahan dan Kawasan Permukiman sehingga kurang melibatkan bawahan dalam membuat kebijakan, kurang memadainya dana yang tersalurkan sehingga pembangunan dilakukan secara bertahap, fasilitas penunjang dalam melaksanakan tugas masih dianggap kurang memadai, kurangnya sosialisasi tentang program pengembangan perumahan yang dilakukan oleh Dinas Perumahan dan Kawasan Permukiman terhadap masyarakat.

\section{PENUTUP}

1. Program pengembangan perumahan yang dilaksanakan oleh Pemerintah Kota Palembang melalui Dinas Perumahan dan Kawasan Permukiman masih perlu dimasukkan ke dalam RPJMD periode selanjutnya mengingat masih terbatasnya kemampuan masyarakat untuk memiliki rumah sendiri;

2. Masih lemahnya pengawasan yang dilakukan oleh Pemerintah Kota Palembang maupun Dinas Perumahan dan Kawasan Permukiman sehingga masyarakat yang tergolong ekonomi menengah ke atas dapat tinggal di perumahan yang disediakan untuk masyarakat berpenghasilan rendah;

3. Pelaksanaan program pengembangan perumahan di Kota Palembang masih sering mengalami kendala yang pada dasarnya diakibatkan oleh keterbatasan dana sehingga pemerintah terkesan tidak serius dalam pelaksanaan program ini;

4. Koordinasi antar instansi/dinas dalam pelaksanaan program pengembangan perumahan ini sudah berjalan dengan baik, hal ini dapat dilihat dari banyaknya instansi/dinas yang terlibat dalam program ini dan melaksanakan tugasnya masing-masing dengan baik;

\section{DAFTAR PUSTAKA}

Arikunto, Suharsimi, Prosedur Penelitian Suatu Pendekatan, Rineka Cipta, Jakarta, 2004

Jones, Charles, O, Pengantar Kebijakan Publik, P.T.Radja Grafindo Persada,Jakarta, 1994

Moleong, J, Lexy, Metode Penelitian Kualitatif (edisi revisi), Rosda, Bandung, 2005

Undang-Undang Nomor 4 Tahun 1992 tentang Perumahan dan Permukiman Undang-Undang Nomor 24 Tahun 1992 tentang Penataan Ruang UndangUndang Nomor 25 Tahun 2004 tentang Sistem Perencanaan Pembangunan Nasional

Peraturan Pemerintah No.39 Tahun 2006 tentang Tata Cara Pengendalian dan Evaluasi Pelaksanaan Rencana Pembangunan

S.K. Menteri Kimpraswil Nomor 217/2002 tentang Kebijaksanaan dan Strategi Nasional Perumahan dan Permukiman (KSNPP) 
P. ISSN: $2540-816 \mathrm{X}$

Volume 3 Nomor 2 Edisi Maret 2021

E. ISSN : 2746-1629 